\title{
Universal Health Coverage Development in Thailand: How Global Ideas and a National Medical Professional Movement Made a Difference
}

Rangsan Sukhampha ( $\nabla$ rangsan.sukhampha@uni-bielefeld.de)

Bielefeld University

Research

Keywords: Global Health, Medical Professional Movements, Universal Health Coverage, Global Ideas Transfer, Thailand

Posted Date: July 12th, 2021

DOI: https://doi.org/10.21203/rs.3.rs-674771/v1

License: (c) (i) This work is licensed under a Creative Commons Attribution 4.0 International License.

Read Full License 


\section{Abstract}

Background: Universal health coverage is endorsed as the global development agenda in the 2015 SDGs for global achievement by 2030 and is expected to build national policymaking agendas. Common research often focuses on national processes in the first place. For example, accounts of Thailand's health system development mostly emphasise domestic factors and influences rather than the linkage of external/global health ideas. The paper questions how external/global health ideas influence national health policymaking and the linkage between them in achieving Thailand's universal health coverage policy.

Methods. A qualitative method was employed to capture complex and historical narratives of the national medical professional movement for Thailand's health system reform through the lens of a global social policy approach for exploring external and global health ideas transfer. Moreover, the actor- and policy entrepreneur approaches would be employed to investigate national health policymaking and examine how ideas from the external and global levels have improved national equity in health.

Results: The research locates the narratives on global ideas and practices that influence a national health system reform. This highlights the impact/role of global ideas on national professional movements, i.e. the rural doctor movement in Thailand mobilising the health system reform for all. The study found that national equity in health could not be achieved without external/global health ideas transfer. Such a case of national universal health coverage achievement in Thailand happened with the effort of the rural doctor movement and individual agency as policy entrepreneurs in translating external/global ideas and practices for their movement and mobilisation. The case contributed to a better understanding of the global process regarding ideas and practices that can be transferred directly and indirectly to the national level.

Conclusions: Global ideas transfer can also happen in different aspects such as it can be seen the ideas transfer from developed to developed countries; from developed to developing countries. Besides, the author witnessed that the IOs ideas can also be transferred to developing countries or reverse, and again, between developing countries themselves.

\section{Introduction}

Global health ideas mobilise health policy transfer across national state borders. The way the global actors transfer their intention can be viewed as ideas and practices that influence national public health reform, in many cases, led by national medical professional movements. Understanding the mentioned global phenomenon has to investigate such an evident case from below when global ideas and practices interplayed at the national and local levels. Herein, the Thailand case study will be taken as evidence of how global health policy transfer, borrowing, and adoption in the sense of a medical professional movement for healthcare reform, especially universal health coverage policymaking. Understanding Thailand's health system reform and UHC policymaking are unenviable to analyse Thailand's 
democratisation atmosphere closely. In some pieces of literature about Thailand's public health movement, McCargo (1) identifies it as one of Dr Prawet Wasi's networks, including Anand Panyarachun and Prem Tinsulanonda and his political thought and movement as a liberal royalist is related to "network monarchy." According to Connors (2), the word "royal liberalism" represented the extrabureaucratic networks that empower them to gain political influence and power in political networking. As a "Senior Citizen" status, Dr Prawet played the dominant role in promoting political and social reformation and movement in 1997 constitutional drafting. However, he proclaims that the clean and moral political discourses have undermined the legitimation of electoral democracy by arguing that those politicians have long been embedded in Thai politics and tend to absolute corruption because they represent the electoral votes they can buy. Simultaneously, he attempts to create the ultimate legitimacy of monarchical moral authority (3).

Aside from the monarchy network concept, some works of literature tend to focus on the public health movement itself, such as Harris work's focuses on professional network and movement for universal health care policymaking, autonomous political networks and health system reform, and the "regulatory capture" challenge to developmental capture of the state and universal coverage policy (4-9). In some aspects, Sapyen's work (4) discusses how the rural doctor movement had innovated a new approach of a social movement which created the duality nature of the social movement in terms of non-governmental organisations (NGOs) within the governmental organisation (GO), whereas maintaining the nature of being GO within NGOs. This is extended to Vongtangswad's work (10), investigating the dynamics of the rural doctor movement in terms of conflicts, including political transformation focus on framings and mobilisation, taking with them three social movement frameworks: resource mobilisation, framing process, and political opportunity structure theories. The rural doctor movement had created a duo autonomy state in the healthcare system's structure. Political opportunity structure change is a vital factor that paves the way and allows the rural doctor movement to adjust framings and mobilisation to push healthcare system reform. Approached political elites, whether democratic or not, in practice, the movement works collaboratively to advocate public participation in some aspects. As aforementioned above, another piece of critical work proposed by Nam (11) focuses on partnering with bureaucrats and NGOs to achieve UHC, which rarely disregards external ideas and practice of the moves.

The above mentioned the existing literature on Thailand's health system reform and public health movement; still, there is a lack of global perspectives and connection as the structure of health governance ideas and practices that widely move globally. Thus, in this paper, the author explores how health policy transfers from global and IOs ideas to a national level and the diffusion of health ideas from developing countries to other developing countries. Furthermore, the author identifies how the national medical professional movement achieved equity in national health based on external and global health ideas in the Thai case study. Also, the linkage between the external/global health ideas and a national health policy and practices will be further investigated.

\section{Methods}


The article explains the global health policy transfer regarding ideas and practices as external influences that a national medical professional movement adopted to fuel UHC in Thailand. In doing that, the author will be employing a global social policy approach and a professional movement for an in-depth investigation of how global health policy transfers by learning, influencing, borrowing, and adopting into a national political context. Then, these global ideas and practices raised in this article will be detail described for further exploration, such as global health governance and its architecture of arguments among actors and glocalisation of global health ideas, global health ideas on universal health coverage and its debates, primary healthcare and health ideas transfer, and roles of the medical profession and associations as mediators for health ideas transfer as such. The latter part takes the policy entrepreneur, and individual agency approaches to investigate how a national medical professional movement interacts with the powerful actors in politics and ensure their implementation by working with the formal power and resource. Thus, the case study also explores the linkage between internal movement and external ideas and practices, insisting that policy changes in particular countries, in one way or another, are often related to a global context.

\section{Results}

\section{The Thai Health System Development and Its Foundation for the Reform}

Modern medicine in the modern Thai state has been gradually developed since the Rama $V$ era (18681910). Healthcare policy was viewed as a tool for strengthening national security and stability under bureaucratic polity centralisation for securing absolute monarchy and elite in Bangkok. Even though the first hospital was built in Phetchaburi province in 1878 initiated by Dr E.A. Sturg, an American missionary, the modern medicine milestone was immensely developed when Siriraj Hospital was established in 1886 (63), department of nursing in 1888 affiliated with the ministry of education. It was recognised as the beginning of a new era of modern medicine and public health in Thailand, which emerged amid various political struggles. The intention of King Rama $V$ to reform and movement had challenged conservatism and the ruling aristocracy. Strengthening the regime stability by decreasing the mortality rate to increasing the population is a critical productive force. However, the concept of happiness that depends on national security and national interests centred on the absolute monarchy was faced with the challenge waves of democratic, constitutional and nationalist concepts that eventually led to the revolution in 1932. This created significant effects on the transformation and development of Thai public health.

The end of World War II envisaged the emergence of ideological tension in the cold war between the two blocs: the US and USSR, which officially started in 1947. The Chinese civil war led by Mao Zedong tends to win over the civil war, the US support Field Marshal Plaek Phibunsongkhram's administration, the coup d'état government in 1947, fighting against the threat from communists. The Cold War paved the way for opening the global and internal political opportunity structure in which the bureaucracy-centralised power still took control over the Thai state. However, the main concept of democracy, constitutionalism and nationalism encouraged by the People's Party (Khana Ratsadon) would be faded, the Field Marshal Sarit 
Thanarat, the coup d'état and traditionalist-conservative group, decided to take over the power of Field Marshal Plaek Pibulsongkram. In 1942, the Ministry of Public Health (MoPH) had established a new challenge force that was dissatisfied with the core paradigm and the structure of political opportunities governing the Thai state. It has happened again under the student movement's leadership has been influenced by socialist liberal democracy. It is a cornerstone of the later era of the public health movement. Instead of focusing on public health for national security, they emphasised inequality, centralisation of power, and resources, changing public health concepts for national security to public health for all people. Along with the first Faculty of Public Health in Thailand under Mahidol University's affiliation established in 1948 and the Faculty of Medicine Ramathibodi in 1965, the stem of the emerging education and movement activities related to rural areas' development. This was one of the factors that led to the subsequent changes in public health framing and movement.

In terms of health infrastructure, in 1947, the department of medical services started building the provincial hospitals according to a governmental policy that demand building the provincial hospitals in all 72 provinces and health centres at the district level during 1952-1957. It largely happened in the time of Field Marshal Plaek Phibunsongkhram's administration (1948-1957) was in power, claimed as the "Golden Era of Building Provincial Hospitals." However, this would not be achieved without the US operation mission (USOM) with financial support for medical instruments. During 1951-1957, the US government provided economic and financial support to the Thai government for \$149 million and financial support to the military purpose for $\$ 222$ million (12). Economic and financial support has been spent on port building in Bangkok, include transportation, train and road, agriculture, education, irrigation, economic planning, public health development, and hospital system expansion.

In the second half of the 19th century, in the 1970s, the Indo-China war and conflicts between communism and democracy across nations in South East Asia and the emergence of the "dominos theory" escalated the concern of communist domination over Thailand. In response, government policy sought to reduce poverty among its population through rural development and improved health, education, and agricultural extension services. Thus, health, along with education and agriculture, became cornerstones of rural development and poverty reduction. The ongoing conflict in the Vietnam War in the 1970s, the US needs to import health personnel from other countries that eventually escalated the shortage of health personnel and the brain drain phenomenon in Thailand. As a result, the Thai government initiated the first national economic and social development plan (NESDP) (1961-1966). In 1965, statistical data from the Office of the Civil Service Commission identified that $52 \%$ of new graduate doctor students have emigrated working abroad. As a result, in 1967, the MoPH introduced a three-year mandatory rural health service placement policy, and the first graduate medical student began working in the rural area in $1972(13,14)$. The rural doctor federal established in 1976; after the 6 October 1976 event, the federal government has to stop its operation. Later, the rural doctor federal, soundly left-wing ideology, has to rename it to the rural doctor society in 1978 to avoid surveillance from the national security agency. The rural doctor society has then elevated to the rural doctor foundation in 1982 as a juristic person that could accumulate capital and mobilisation such as social, intellectual and financial capitals. 
The rural doctor movement has been growing in the career path, promoted to a higher position and connected to the senior doctor in the Ministry of Public Health. Some degree of conflicts happened between the doctors who tend to serve the central government policy and the doctors who have been working in rural areas. Sampran Group established in 1986 under senior doctor's support, such as Dr Prawet Wasi and Dr Sanguan Nitiyaramphong. In the beginning, Sampran Group's main purpose is to organise the monthly academic forum for ideas exchanges and academic meetings in public health service and administration with financial support from WHO Thailand since August 1986. Later, the Local Development Institute (15) and Local Development Foundation has been established with the Local Development Assistance Program (LDAP) support, funded by the Canadian International Development Agency, launched in 1984 for the five-year project from October 1984 to March 1990, approximately CAD\$ 5 million.

The immensely change in the Thailand health system happened when the government dedicated to primary healthcare as a recently UHC foundation since the 1970s. It began in 1977 during the 4th fiveyear National Economic and Social Development Plan (NESDP) (1977-1981) that initially emphasised primary healthcare and investment in the health infrastructure at the local level, especially the district (in the 1990s) and sub-district level (in the 2000s). Also, intentional policies enlarged health staff's internal training and spread over to underserved areas and populations (16). After four decades of health infrastructure development and three decades of designing and implementing many different financial risk protection schemes before the UHC launch, pilot phases in 2001, and four main public health insurance schemes covered four major population groups. The Civil Servant Medical Benefit Scheme (CSMBS) (1978) covered approximately $9 \%$ of the population. A social security scheme (SSS) (1991) for workers in the formal sector covered about $7 \%$ of the population. Another $28 \%$ of the population purchased health insurance coverage through a subsidised Voluntary Health Card (VHC) program (1983). A Low-Income Card (LIC) program (1975) targeting the poor covered an additional $23 \%$. Less than $2 \%$ of the population purchased private insurance coverage, and the remaining $30 \%$ went without any coverage $(5,17)$.

According to the National Health Security Act $2002(18,19)$, a law comprises the cooperation of different sectors amid the participatory development flow under the 1997 Constitution of the Kingdom of Thailand. In Sect. 76, the constitution was given that the state shall promote and encourage public participation in policymaking, and in Sect. 303 and 304 for inspecting the exercise of state power at all levels (20). Furthermore, the first constitution contains provisions of "the right of initiative" to propose a new law, as shown in Sect. 170, which has given at least 50,000 voters to petition the National Assembly president to propose a law. Besides, the Constitution of the Kingdom of Thailand BE 2540 (1997) also focuses on promoting and protecting the rights and liberties of the people, increasing public participation in governance and monitoring of the exercise of state power, as is evident in the Constitution of the Kingdom of Thailand 1997, part 3: Rights and Liberties of the Thai People, and part 5: Directive Principles of Fundamental State Policies. While the 8th National Economic and Social Development Plan (19972001) began to differentiate the direction from the other National Economic and Social Development Plans (NESDP) formulated only by government agencies. It started with providing opportunities for all 
professional groups to widely express their opinions for setting the country's development direction instead of setting plans only from the government sector. This created the development paradigm shifts from economic development to a people-centred development for sustainability $(17,21)$.

As a result, Thailand achieved UHC since 2002 (pilot phase in 2001) and provided three main categories of Thailand's Health System: the UCS covered 48.8 million people accounted for $70 \%$ of the Thai population; the Civil Servant Medical Benefit Scheme (CSBMS) covered 4.97 million accounted for $10 \%$ of the population that were government employees, retirees and dependents; and Social Security Scheme (SSS) covered 13.09 million private-sector employees accounted for $20 \%$ of the population (16).

\section{How Global Ideas and a National Medical Professional Movement Made a Difference}

The overview of the paper will present in the two main parts. The first part reviews external and key global/transnational health ideas and how global ideas transfer to the national level. These global ideas will be raised related to the national context of health system reform and policy agenda-setting that are; architecture of arguments in and glocalisation of global health ideas, global health ideas on universal health coverage and its debates, primary healthcare and health ideas transfer, including roles of the medical profession and associations as mediators for health ideas transfer. The second part discusses internal movement in macro-level context (such as the institutional and structure faces of context) and micro-level context (such as agency-level enabling conditions) (see the similar approach of Bakir and Jarvis (22)). Then it spotlights how internal movement portrays policy entrepreneurs' roles and its networks perform in the Thai health system reform (see Fig. 1 below).

\section{How Global Ideas Made a Difference: External/Global Health Ideas Transfer}

\section{The Architecture of Arguments in and Glocalisation of Global Health Ideas}

The establishment of WHO in 1948 have underlined transnational aspects of health problems, and the states admitted as membership and committed their initiatives to their national health policy (23). Global health governance in global social policy literature as a discipline mainly investigates social policy issues perceived in the global/transnational scope (24). This larger scope in terms of policies and actors engaging in global healthcare created diverse ideas and discourses that led to a contested argument, such as a case of IOs and global social governance (see Martens, Niemann, and Kaasch (25)). According to Kelley Lee (18), this sense can be related to the contested global idea construction being classified as a cognitive dimension of globalisation. In this case, the thought processes are not limited to the global north initiation, but international organisations' ideas and practices like WHO, IOs as global health actors have cognitive authority over a specific field for global ideas and practices prescriptions. The approaches 
used for health, which developed at the global level steered by an international organisation like WHO, are important, but the key focal point should be national translations and local actions (26-29). These local policies impact global change through multilevel policy diffusion that demand assessment and analyses of local government effectiveness, especially in the late 1980s and early 1990s. That led to introducing the terms "glocal and glocalisation" for multilevel policy analysis (30), in which, according to llona Kickbusch (31), the lexicon 'glocal health', describes a reciprocal interaction and the intricate and inseparable interface between global health actors' ideas and practices and local responses for equity in health. Therefore, the glocalisation dynamic is reciprocal (32-34). Understanding global health ideas transfer, it is necessary to portray the global health ideas structure of arguments. Dealing with this matter can be seen in Deacon's work (35), global social policy consists of social policy prescriptions for national and supranational social policies regarding redistribution, regulation and rights. In line with Kaasch's work (36), which discusses the conceptualisation of global social policy in its dimension of prescriptions on national social policy on pensions and health systems reveal contesting contestation concerning notions of the 'war of positions'. In addition, Kaasch's latest work (37) proposes mapping the four main IOs in global health governance focus on the IOs matter of health care system: WHO, World Bank, the ILO, and the OECD and characterising the global health architecture based on contestation and collaborative manner between them. Similarly, this article discusses the conceptualisation of global health actors as health policy prescriptions and the attempt of global health ideas transfer to a national level.

This context, debate about and argument for Thailand's UHC initiative can be viewed as a contestation of global health ideas that witness some level of conflict among global actors and ideas. UHC matter what services are covered. How they are funded, managed and delivered to the poor and vulnerable groups. As such debate in 2001, in the time of Thailand's GNI per capita was around US\$1900, WHO voices strongly support of UHC implementation from the taxation even though Thailand just recovered from the financial crisis in 1997. On the other hand, the World Bank strongly critiqued and warned that the country would eventually face a public financial collapse and bankrupt public hospitals. The bankrupted financing system will dilute health care quality if Thailand is still stubborn to do so. In addition to the World Bank stance, former prime minister Chuan Leekpai, a Democrat, was aggravate by disagreement in the Parliament in 2002, emphasising that the national budget was not only for the health sector (8). Thus, the author witnessed the linkage of global ideas and discourse concerning Thailand's health system reform and created a better understanding of how the global and national linkage existing in one way or another.

\section{Global Health Ideas on Universal Health Coverage and Its Debates}

The UN post-2015 development agenda, so-called Sustainable Development Goals (SDGs), has initiated 17 goals and 169 targets. The concept of UHC is indicated in Goal 3: Ensure healthy lives and promote well-being for all at all ages, which is articulated clearly in targets 3.7 (universal access to sexual and reproductive healthcare services) and 3.8 (achieving UHC agenda) (38). The UHC in various countries worldwide witness the immense extension of the concept in the developing countries in Eastern Europe and Asian countries. WHO defines UHC as a healthcare system that allows "all people have access to the 
health services they need, when and where they need them, without financial hardship, includes the full range of essential health services, from health promotion to prevention, treatment, rehabilitation, and palliative care." In practice, some low and middle-income countries (LMICs), such as Brazil, Ghana, Mexico, Rwanda, Turkey, including Thailand, are implementing reforms to make health care universally available (39). In the Global South, UHC moves countries away from cost-sharing policies towards universal access to free or heavily subsidised health care and focuses on the state's obligations to its citizens. Crucial to UHC introduction are questions of financial risk protection, whether through taxes or required prepayment and pool risk (40). Unlike the European welfare states, in most LMICs, state social protection has been limited to specific groups such as civil servants or people in the formal economy. This limitation of state social protection raised the importance of UHC as the most powerful concept that public health has to offer for alleviation of health inequity. UHC, herein, defines it as the right to access government medical care for all Thai people who were not covered by civil servant medical benefits scheme (CSMBS), social security scheme (SSS) (formal sector) or other state enterprise welfare rights (41). It provided public health services, health disease prevention, diagnostic examination, and medical treatment and rehabilitation necessary for health and livelihood. For this reason, understanding how a particular country in the global south can achieve UHC for equity in national health would inspire other countries in the same range to do so.

\section{Primary Healthcare and (Global) Health Ideas Transfer}

Before the 1978 Alma Ata Declaration on primary healthcare, the community performed vital roles for healthcare as collective action in health throughout human history. Nowadays, the local actor of PHC, the so-called "Village Health Workers (VHWs)", can be traced back to Chinese barefoot doctors, the former "Soviet's Rural Feldsher", as well as "Thailand's Village Health Volunteers (VHVs)" $(42,43)$. A narrative on a local doctor responsible for taking care of people in remote rural areas that applies local wisdom, traditional healing techniques with herbs and folk medicines has existed for a long time. But, rural doctors' actions relevant to political movements and social change are exposed as historical records in the modern state $(44,45)$. The barefoot doctor has the main function to promote hygiene, disease prevention, and basic healthcare and family planning, treatment for common ailments $(46,47)$. The transnationalisation across the national border, both tangible and intangible aspects, had occurred throughout human history. That escalates the diffusion of norms and ideas in various dimensions include healthcare ideas from place to place beyond national boundaries, both from global health actors, like WHO, to nation-states and from the nation-state to nation-state themselves. In the Thai case, WHO, as a global actor, has first introduced the PHC concept in the north of Thailand operated as a pilot project, namely the "Saraphi Project", launched in 1969 (21). The South-South health ideas transfer happening in Thailand during the malaria epidemic in the late 1950s resulted in the increasing demand for health workers to deal with the epidemic. While medical personnel were a few, community health volunteers were trained to tackle the epidemic and eradicate malaria during 1961-1962. Later on, it named Village Health Volunteers (VHVs) with the push forward of the People's Liberation Army of Thailand, which has been operated during the 1940s and the 1990s (48). However, VHVs became more concrete under the 4th National Economic and Social Development Plan (1977-1981) during the Kriengsak Chamanand's 
administration. In this vein, VHVs play an important role in the Cold War mass struggle; many people fled into the forest compound with the villagers, intellectuals and doctors as members of the People's Liberation Army of Thailand fight against the central government. Therefore, the so-called "Barefoot Doctor" derived from the characteristics of barefoot healthcare activities while working in the field as such in the People's Liberation Army of Thailand. In sum, Thailand's VHVs idea has been influenced by the "Chinese barefoot doctor" concept was transferred through the mass movement that came across the national border. In addition, the aura of barefoot doctors' success in terms of access to medical treatment of rural people in the distant areas inspired the 1978 World Health Organization Conference on Primary Health Care, where the meeting finally agreed to launch the Alma-Ata Declaration (49). Still, these global health ideas have a major impact on PHC adoption at the national level around the globe, which $\mathrm{PHC}$ is the foundation for UHC achievement in LMICs, as can be seen in the Thai case will be later discussed in the next part.

\section{Roles of the Medical Profession and Associations: Mediators for Health Ideas Transfer}

Related literature to professional movement, Harris's work (7) examines the effort of professional movements in expanding access to healthcare and AIDS medicine in Thailand, Brazil, and South Africa. Harris mentioned the rural doctor movement in Thailand as 'progressive doctors' who played an imminent role in UHC policymaking. In Brazil, a similar movement of medical professionals concerned with public health played key roles in drafting legislation in the Health Ministry and promoting programs to bring health care to the masses and hold the state accountable. However, South Africa made only incremental gains because the government actively obstructed professional movements seeking more transformative reform. In Thailand, the Rural Doctor Society, a national medical professional movement, does not stand alone, but they also engage with global health ideas derived from WHO, ILO, World Bank (48). Even though these global actors did not directly influence the UHC implementation, where they were involved, the Health Minister requested the assistance of the WHO and the ILO to run a technical seminar that strongly gave positive support to the reform. Besides, the EU funded the healthcare reform program and technical and research skills the EU provided to many medical doctors through the training program at medical schools such as Antwerp University and the London School of Hygiene and Tropical Medicine (21). As mention above reveal how a national medical professional movement in particular countries has been influenced by global health ideas and practices to move forward with national health reform.

\section{How A National Medical Professional Movement Made A Difference}

\section{Internal Movement: Policy Entrepreneurs, Partnerships Building and Network Governance}


Prominent scholars in sociology and political science have pointed to the importance of changes in "political opportunity structures" (50), "windows of opportunity" (51), and "critical junctures" (52) to social and policy change. This section investigates the roles of policy entrepreneurs in the policy process and agenda-setting of health system reform related to Kingdon's Multiple-Stream Framework (MSF) (51) that outlines the policy process situated into problems, policy and politics. According to Kingdon, political entrepreneurs are most active in the policy stream to create solutions to potential problems and bring them forth to the agenda-setting process (51). In this similar vein, Brasil and Capella (53) illustrate the roles of policy entrepreneurs (individuals and sometimes small groups of people) in the public policy process in terms of agency for translating ideas into action. Thus, the concept of policy entrepreneur will be employed for exploring UHC policymaking and agenda-setting. In the first step, the author explains the historical narrative concerning the Thai health system development as a foundation for the recent reform. Then, the later step will be the investigation of other topics such as professional movement focusing on the individual agency as policy and institutional entrepreneurs in terms of a change agent in health reform and how rural doctor movement as policy entrepreneur builds partnership with bureaucrats and advocacy coalitions, include how the networks are governed (see Fig. 1 above).

\section{Professional Movement: Policy and Institutional Entrepreneurs in Health System Reform}

In the first place of problem stream, in this case, policy entrepreneur has played a critical role in knowledge accumulation and production related to health system reform as the basis for evidence-based policymaking to achieve the UHC. An individual agent led by Dr Sanguan Nittayaramphong, the key rural doctor movement's leader, has dedicated the working life and resources (e.g. vision, skills expertise, and leadership) to pro-poor healthcare development suitable for rural areas in Thailand. The rural doctor movement's role in achieving UHC has rooted in the rural doctors' group who faced scarcity, and difficulties in their working conditions first met in April 1976. The like-minded doctors come together to share, exchange and help each other in various matters. The first meeting was held in Khao Yai, Pak Chong District, Nakhon Ratchasima Province, and a coalition of rural doctors was finally established. Before establishing the Rural Doctor Society in 1978, Dr Uthen Jaranasri was the society's president, while Dr Manit Prapansilp was a secretary, and Dr Suwit Wibulpholprasert was the secretary assistant. The society intends for professional development, according to the society's objectives statement as follows; being a centre for exchanging ideas of rural doctors across the country; reinventing services and academic knowledge of rural doctors nationwide; improving the efficiency in services, and raising a practising physicians status in rural areas to be well recognition (54).

During that period, the rural doctor movement has operated mainly on implementing rural hospital development and building a rural doctor society network in different regions that later become a legally registered NGO as the Rural Doctor Foundation in 1982 by conducting social movement activities. Most of the foundation's roles are mainly operated in the form of funding and publishing of journals and the society's brochures, while the rural doctor society is more flexible in terms of social activism (14). The 
rural doctor movement is also driven based on knowledge derived from an academic forum and discussion; the Sampran Group, a rural doctor group, gathers to exchange and disseminate global ideas and knowledge transfer, with main support from WHO Thailand. It was held every month at Suan Sampran (Rose Garden) in Nakhon Pathom Province since August 1986, as Dr Prawet Wasi advised Dr Sanguan Nittayaramphong, where the forum also consulted the difficulties of work condition and the rural doctor's bitter feeling. Dr Sanguan Nittayaramphong worked at the Office of the Primary Health System Committee embedded in a bureaucratic structure with a vertical management system and a lack of autonomy; this is different from the working condition in a district hospital which the doctor could play the leading role in relation to other governmental body in the area. Therefore, Dr Sanguan Nittayaramphong preferred to arrange a discussion to adjust and understand the rural doctor movement. Dr Prawet Wasi's recommendation establishing an academic platform in this knowledge-building forum would reduce incomprehensibility between the rural doctors who enjoy the central power in the MoPH and the others who demand local change in the rural areas. The Sampran Group forum was organised every month; the main groups of rural doctors attending the meeting are Wichai Chokwiwat, Chuchai Supawong, Ampol Chindawatana, Suwit Wibulpholprasert and Sanguan Nittayaramphong. Some senior rural doctors are members of the Samphran group, namely Phairot Ningsanont, Thansiri Panich, Darong Bunyuen, and Prawet Wasi, as highly respected rural doctors attended the forum every time for decades.

The rural doctor movement's operation became clear in 1987, additional committees were appointed (55). During this period, Thai doctors in the United States and the American Medical Association gathered donations to conduct research projects for decreasing infant mortality rate and early neonatal mortality rate reduction. One successful project is the 'Running Campaign for No Smoking' in October 1987, asking for a referendum to support the No-Smoking campaign that operated parallel with 'Doctor Visit' Program in community hospital. The first foundation program was developed during 1987-1988; the roles of the rural doctor movement (both the society and the foundation) was increasingly clear. The functions are divided under two main mechanisms: the Rural Doctor Society is an informal organisation, not a legal entity with high mobility; and the Rural Doctor Foundation is a funding source (both social capital, intellectual capital, and financial capital), a formal organisation, a legal entity working in reconciliation and protection. During this period, there have been many important activities of the Rural Doctor Society, particularly the promotion of UHC led by Dr Sanguan Nittayaramphong.

Dr Sanguan Nittayaramphong, who chaired the Rural Doctor Society during 1985-1986, was a coordinator with various sectors. The first emergence of the UHC initiative was sparkle when he has worked in rural hospitals. In the latter few decades, he started the Khun Han's operational research project at Khun Han District, Sisaket Province, during 1986-1988, with participants from the university, MoPH and health workers in the area. The aim was to observe the health service operation and provide academic assistance in solving the operational problems. This research revealed that most patients came to the hospital with common illnesses and diseases, patients could take care of themselves. As a result, the research recommended improving public health strategies and its focus directly to the community level, and villagers were encouraged to take better care of their health and their families. Besides, it was found that the doctors' prescribing behaviour in Khun Han Hospital was not at an 
excessive level. Thus, the average doses of drugs cost compared with the health centres drug use for the same medical treatment help estimate the cost of services, and improve the health centre's capacity in common illness treatment. The study of such rural hospitals' situation led to the UHC prototype project, namely the Ayutthaya Project during 1989-1994, to reform the health service system at a larger scale. The experiment created a patient-centred integrated health system and collected the treatment fee at 70 baht per visit set by the hospital and community's agreement. After the 2-year performance of the Ayutthaya Community Medical Centre at Wat Intharam, the centre still operated normally under regular support from the state budget. In addition, general hospitals, municipalities and medical centre staff are satisfied with their operations. This successful project later expanded to a national project called the Health Care Reform Project, funded by the EU at approximately US\$30,000 (56). The ideas and experiences derived from the Ayutthaya Project mobilised the public health reform in terms of financing, personnel, referral system, and then expanding operations to other provinces.

In addition to the healthcare research project mentioned above, the rural doctor movement institutionalised evidence-based knowledge production to support reforming the health system. The socalled Health Systems Research Institute (HSRI) originated from the National Epidemiological Committee forum chaired by Dr Prawet Wasi. After a meeting with the Minister of Public Health, Dr Phairot Ningsanon agreed that the reforming principle led to establishing HSRI in 1992. HSRI performs academic functions, knowledge management, and a systematic knowledge base to drive health system reform. The rural doctors relied on evidence and knowledge-based reform as the most important step to drive the health system reform, and such systematic knowledge must also acquire from an independent health systems research institute. Dr Sanguan Nittayaramphong, a key rural doctor, played a role in drafting the Health Systems Research Institute Act and pushing the Legislative Assembly to ratify it at the Last-day meeting. After establishing the HSRI, Dr Somsak Choonharas was elected as the institute's first director, assigning a committee and laying the foundation for the HSRI to work independently in the knowledge production necessary to drive the health system's reform (57).

In addition to institutional entrepreneurship accumulated knowledge in support of public health reform, $\mathrm{Dr}$ Sanguan Nittayaramphong has written a yellow book to describe UHC in terms of background, possibility, and budget required for achievement approximately baht 30,000 million (58). Also, he has even engaged in social security and rights to healthcare access and the Public Health Commissioner for drafting the National Health Security Act during 1993-1994. Therefore, he attempts to expand the right of healthcare access to cover all population. However, no political parties were interested in the UHC policy he proposed, except Thaksin Shinawatra, the newcomer Thai Rak Thai Party leader. A team consisting of highly skilled doctors, for example, Dr Viroj Tangcharoensathien, who have participated with the foundation for a capitation system in social security in 1990, which was different from the CSBMS's feefor-service system, which was later developed into a social security scheme setting co-payment rate per capita 700 baht per year in the beginning. In 2001, it adopted a per-capita package for UHC at the per capita rate of 1,202.40 baht per year. Aside from Dr Sanguan Nittayaramphong, Dr Wichai Chokwiwat is also another one who plays an important role in presenting the UHC to Thaksin Shinawatra. Rural 
doctors' coordination based in the MoPH, Mongkol Nasongkhla, Suwit Wibulpholprasert and Dr Prawet Wasi's network was drivers to achievement $(16,21)$.

Therefore, the rural doctor movement's essential component is a knowledgeable leader since identifying social issues concerning the nature of policy problems related to a broader population and policy agendasetting. The rural doctor movement pushes forward UHC through continuous research and experimentation that officially started as an operational research project during 1986-1988, brought about to create the UHC prototype, the so-called "Ayutthaya project". During 1989-1994, the Ayutthaya project was introduced as the prototype for health system reform and development at a larger scale.

Later, it expanded to a national project called the "Public Health Service Reform Project", in which the ideas and practices derived from the Ayutthaya Project. These ideas and practices in public policy driven by evidence-based health system research eventually transform into an institutionalised body like HSRI the rural doctor movement got immensely involved. The cumulating evidence-based knowledge encourages the rural doctor movement's stronger position to push forward the UHC when the appropriate condition and policy window of opportunities have opened. Besides, the rural doctor movement expanded the network linkage to various social sectors, especially Dr Sanguan. Nittayaramphong is a bureaucrat based in the MoPH, involved in a political sector in the Thai Rak Thai Party and NGOs. Getting involved in the rural doctor movements with multiple networks originate prompt advocates for achieving the UHC.

\section{The Partnering of the Professional Movement, Bureaucrats and Advocacy Coalitions}

Since 1975 in the Kukrit Pramoj's administration, the Thailand health system has begun profound development in the district hospitals. Later, the Prem Tinsulanonda's administration has immensely built community hospitals in the district and health centres in the subdistrict. Then, it was elevated to the SubDistrict Health Promoting Hospital (SHPHs) in the Abhisit Vejjajiva's administration (59). The health infrastructures spread covers all areas, supporting healthcare access for all in the future. Before the UHC establishment, medical expenses for low-income people can be waived. The government launched a medical welfare scheme for poor and vulnerable citizens in 1975, covered $13 \%$ of low-income households assessed on income and assets. It later increased to $28 \%$ in 1996, combining the elderly, children, disabled, monks, novices, and veterans (60). Even though the state launched additional voluntary health insurance with government support for partial contributions, before initiating the UHC in 2001, many were still left behind and not be counted in a medical welfare scheme for poor and vulnerable citizens, voluntary health cards, social security scheme, and the CSMBS.

Healthcare access does not cover the entire population tend to create problems the rural doctors have to face in the rural hospital. Therefore, knowledge was accumulated, ready for solutions. The 1997 Constitution pave the way before the first election would be organised. In December 1999, Dr Sanguan Nittayarampong had presented the UHC to Thaksin Shinawatra, the Thai Rak Thai Party leader, with doctors who were wielding power and vital role in the party: Prommin Lertsuridet and Surapong Suebwonglee. From the political situation at that time, together with the 1997 constitution, it became a 
policy window of UHC. This constitution designs a political structure to promote a strong government and leadership. This makes it possible to drive a large policy and the intense demand for citizens' rights after the political reform, and all stakeholders realised the importance of advocating policies from the public sector. The 1997 constitution also ensured medical treatment as a fundamental right that the state had to provide to its people, according to Sect. 52 and Sect. 82. Gathering alliances to push forward the UHC includes the rural doctor movement, academics, and affiliates; the health organisation network has actively driven the proposal.

The Thai Rak Thai Party finally endorsed the UHC concept, which was included as one of the nine electoral campaigning policies in the 2001 election of the House of Representatives. The slogan "30 baht treats all diseases" was raised to competing in electoral campaigns. Subsequently, after the victory of the 2001 election, Thaksin Shinawatra announced the government's policy statement on 26 February 2001, committed various policies such as urgent policies, economic policy, income building policy, international trade and economy policy and others. UHC is one of nine urgent policies for the implementation so that the state could reduce the overall expenditure on individual health care given at a maximum cost of 30 baht per visit and include creating equity in healthcare access for all. Therefore, the government has cooperated with the rural doctor movement as NGOs seriously, partnering with a like-minded doctor based in the MoPH, Mongkol Na Songkhla, as the Permanent Secretary, MoPH (11). Thus, great momentum for the movement has occurred for implementing the UHC initiative. According to Harris (8), the Thai case directs our attention to bureaucrats' capacity to create policies in the absence of legislation and implement the policy before becoming law as a pilot project. It was not until April 2001 that the pilot phase's UHC system was launched in six provinces: Phayao, Nakhon Sawan, Pathum Thani, Samut Sakhon, Yasothon and Yala. It was extended to additional 15 provinces in June 2001 and expanded nationwide on 1 April 2002.

However, advocating the UHC agenda setting and implementation caused severe institutional changes of $\mathrm{MoPH}$, which emerged the resistance of health personnel who claimed that the UHC would potentially destroy the public health system in the long run. Those healthcare workers insisted that the UHC create over workload and messy implementation; some medical workers wear the black armband as a symbolic protest against the system, known as "black arm doctor". The two competing ideas seem increasingly clash all the time. According to Dr Surapong Suebwonglee, making UHC matters is not a sudden agenda, which provides healthcare access for 30 baths for all treatment alone do not efficient enough. So, the national public health financing reform as a whole must be reallocated. The public finance allocation for MOPH hospitals was changed from a supply-side based allocation to a demand-side based allocation with per-capita budgeting (61). In addition, the payroll system was centralised to ensure that healthcare workers still receiving a salary.

\section{Governing Networks for Achieving Universal Health Coverage}


The knowledge accumulation and production of the rural doctor movement dedicated for decades are considered in preparation for health system reform when the political opportunity structure was opened. In addition to this, the rural doctor movement also played an active role as professional lobbyists and network governance. After the "Black May" event in 1992, the new constitution reveals the major political reform and public participation. The public awareness was created that can be seen from the overwhelming victory in the Thai Rak Thai Party over the general elections, which adopted the UHC initiative as one of the vital political campaigns. As a result, this increased partnering with cross-sector cooperation to achieve the UHC. In 2000, the NGOs network planned joint activities to promote UHC under the campaign for UHC initiative. Partnering of the public health NGOs and 11 CSOs networks; namely, the networks of children, women, the disabled, consumer, HIV/AIDS, elderly, slum, alternative agriculture, southern village bank, community welfare group, formal and informal labour groups, and later, health network for the poor as the 12th networks, were the network governance for achieving the UHC. The partnership of 11 organisation networks consist of academics representatives from the public sector, and the Lawyers Council established the legal framework and compiled a list of supporters to draw up the UHC Act. Following Sect. 170 of the 1997 Kingdom of Thailand Constitution, at least a 50,000 voters list could petition a legislative proposal to the National Assembly president (20). A forum was organised at the Teachers' Council of Thailand on 11 October 2000 to compile a 50,000 voters list, led by Dr Sem Pringphuangkaew, Dr Prawet Wasi, Jon Ungphakorn, Dr Sanguan Nittayaramphong, and other networks. There were approximately 600 people have participated in the forum. Eventually, a list of 62,412 voters was submitted to the Parliament on 26 March 2001; it took about five months to review the entire list. Unfortunately, only a list of 44,946 voters was qualified; the network had to find an additional list of 9,481 voters by 30 days. It took at least ten months competing for the submission process, and on 29 January 2002 , the compilation of a list of 50,000 voters was ready (62).

The delays prevented the Act submission timeously under parliamentary procedures for the government and opposition party legislation in the House of Representation on 22 November 2001. However, the network proposed the legislative proposal on behalf of the Public Health Commissioner of the House of Representatives, five of representatives were from the public sector engaged in the legislation procedure of the Extraordinary Commission of House of Representative and three of representatives engaged in the Senate legislation procedure (63). Later, the National Health Security Act 2002 was publicly published in the Government Gazette on 18 November 2002. In addition to legal procedures, People's networks are also involved in the movement to achieve the UHC by campaigning and distributing the initiative to the public sphere through various channels such as hosting radio and television programs, organising public forums, and disseminating know-how in 'smart buyer magazine'. According to the Act, the National Health Security Committee consist of representatives from various sectors. Therefore, partnering across the sectors of society, CSOs, bureaucrats, political parties, and other advocacy groups, especially the rural doctor movement, has played an eminent role in producing knowledge and governing the networks in driving for achieving the UHC (11).

\section{Discussion And Conclusion}


Many countries have been faced with transnational health issues that demand cooperation beyond the state border, and this phenomenon opens an opportunity for the global and transnational actors to play an immense role in coping with the challenges. The article has explored the linkage between external influences of global health ideas and internal professional movement in achieving the UHC policy in Thailand and locates the narratives of the vital global ideas and practices the rural doctor movement in Thailand consider mobilising the health system reform for equity in health for all. The global trends on the UHC had endorsed in the SDGs for global achievement by 2030 , especially in low-income countries.

To our knowledge on transnational policy transfer, this paper attempts to fill the gap of knowledge in the field and identify mechanisms and communication channels for multilevel policy transfer. The paper locates the narratives on (global) health ideas transfer to a national health system reform. This highlights the impact/role of global ideas on national professional movements, as such the rural doctor movement in Thailand in mobilising the health system reform. The findings reveal that (global) health ideas transfer perform through idea transfer instruments, mechanisms and communication channels in multilevel contexts from the global to the national, or reverse. Furthermore, global health idea transfer can happen not only from IOs to national states in a vertical sense but also happen between the national state and national state in a horizontal sense. Most literature on Thailand health system reform often focuses on national processes in the first place $(5,8,9,11,63-69)$. In practice, national equity in health could not be achieved without external/global health ideas transfer, such a case of national universal health coverage achievement in Thailand happened.

In terms of health idea translation at the national level, the rural doctor movement and individual agency as policy entrepreneurs translate external/global ideas and practices for their movement and mobilisation. Some scholars investigate policy transfer and transmissions among developed countries or from developed countries to the developing world $(70,71)$. This paper exposes the transnational policy transfer in ideas and practices across actors such as policy transfer from IOs to developing countries or reverse, and from developing countries to developing countries themselves. These global ideas related to the national context of health system reform and policy agenda-setting that are; architecture of arguments in global health ideas (37) and its glocalisation (31), global health ideas on universal health coverage and its debates, primary healthcare and health ideas transfer, including roles of the medical profession and associations as mediators for health ideas transfer. The global and national linkage exists in one way or another in different forms, such as the international forum and financial aid for health infrastructures and project development.

On the other hand, internal movement can explore in macro-level context (such as the institutional and structure faces of context) and micro-level context (such as agency-level enabling conditions) (see the similar approach of Bakir and Jarvis (22)). The global ideas and practices transfer to national health reform must be adjusted and suitable for a particular national context. Prominent scholars have pointed to the importance of changes in "political opportunity structures" (50), "windows of opportunity" (51), and "critical junctures" (52) to social and policy change, with the roles of policy entrepreneurs in the policy process and agenda-setting that may result in high impact policy and social change. This policy 
entrepreneur, in this study, actively engaged in health system reform related to Kingdon's Multiple-Stream Framework (MSF) (51) that outlines the policy process situated into problems, policy and politics. In a similar vein, policy entrepreneurs (individuals and sometimes small groups of people) also play roles in the public policy process as the agency for translating ideas into action (53).

In sum, it can be seen that, in this case, the UHC could not possibly be achieved without the effort of the national social movement, as a policy entrepreneur who is selling ideas to policy-makers and steer the translation of these ideas to policymaking and implementations. In this case, the rural doctor movement as an individual agency translates global health ideas for building institutional entrepreneurs and adopted them into the national process of knowledge accumulation and production for building evidencebased policy when the political opportunity structure was widely opened. In sum, the Thai case contributed to a better understanding of the global health process of ideas and practices dissemination to the national level with the national movement's support in adopting global ideas and practices, partnering of multiple groups and governing network for achieving the initiatives the others countries can learn from this experiences.

\section{Abbreviations}

WHO

World Health Organisation; NGOs:Non-Governmental Organisations; HSRI:Health Systems Research Institute; AMA:American Medical Association; CMA:Commonwealth Medical Association; PHC:Primary Healthcare; SDGs:Sustainable Development Goals; LDI:Local Development Institute; NESDP:National Economic and Social Development Plan:CSMBS:Civil Servant Medical Benefit Scheme:SSS:social security scheme:VHC:Voluntary Health Card:UHC:Universal Health Coverage:RCMS:Rural Cooperative Medical Systems; PAOs:Provincial Administration Organisation; SAOs:Subdistrict Administration Organisation

\section{Declarations}

\section{Ethics approval and consent to participate}

Not applicable.

\section{Consent for publication}

Not applicable.

\section{Availability of data and materials}

Not applicable.

\section{Competing interests}


The author declares no competing interests.

\section{Funding}

No funding was received for this research.

\section{Authors' contributions}

Not applicable

\section{Acknowledgement}

The author deeply appreciates Prof Dr Alexandra Kaasch, a doctoral supervisor, for her general support, including constructive and invaluable comments on several drafts of the article. The author also acknowledges support for the publication costs by the Open Access Publication Fund of Bielefeld University.

\section{References}

1. McCargo D. Network monarchy and legitimacy crises in Thailand. The Pacific Review. 2005;18:499519.

2. Connors MK. Article of faith: The failure of royal liberalism in Thailand. Journal of Contemporary Asia. 2008;38(1):143-65.

3. Winichakul T. Toppling democracy. Journal of Contemporary Asia. 2008;38(1):11-37.

4. Sapyen CA, Study of Rural Doctor Movement in the Policy Process of Health System Policy. The Movement of Civil Society and Its Contribution toward Participatory Democracy in Thailand. [Monograph]: Chulalongkorn University; 2013.

5. Harris J. Uneven inclusion: consequences of universal healthcare in Thailand. Citizsh Stud. 2013;17(1):111-27.

6. Harris J. A right to health? professional networks, HIV/AIDS, and the politics of universal healthcare: [Madison, Wis.]: [University of Wisconsin-Madison], 2012.; 2012.

7. Harris J. Achieving Access: Professional Movements and the Politics of Health Universalism. New York: Cornell University Press; 2017.

8. Harris J. "Developmental capture" of the state: explaining Thailand's universal coverage policy. J Health Polit Policy Law. 2015;40(1):165-93.

9. Harris J, Selway J. Exchange. Explaining the Passage of Universal Healthcare in Thailand. Journal of East Asian Studies. 2020;20:99-119.

10. Vongtangswad N. The Dynamics of Framing and Mobilization of the Rural Doctor Movement: Conflicts and Political Transformation (in Thai) [Monograph]. Chulalongkorn University; 2017. 
11. Nam I. Partnering for Universal Health Coverage in Thailand: Bureaucrats and NGOs. Asian Surv. 2018;58(2):213-39.

12. Bell D. The World and the United States in 2013. Daedalus. 1987;116(3):1-31.

13. Tangcharoensathien V, Tisayaticom K, Suphanchaimat R, Vongmongkol V, Viriyathorn S, Limwattananon S. Financial risk protection of Thailand's universal health coverage: results from series of national household surveys between 1996 and 2015. Int J Equity Health [Internet]. 2020 2020/09//; 19(1):[163 p.]. Available from: https://doi.org/10.1186/s12939-020-01273-6.

14. Maeda A, Araújo E, Cashin C, Harris J, Ikegami N, Reich MR, editors. Universal Health Coverage for Inclusive and Sustainable Development: A Synthesis of 11 Country Case Studies2014.

15. AbouZahr C, Cleland J, Coullare F, Macfarlane SB, Notzon FC, Setel P, et al. The way forward. Lancet. 2007;370(9601):1791-9.

16. Tangcharoensathien V, Witthayapipopsakul W, Panichkriangkrai W, Patcharanarumol W, Mills A. Health systems development in Thailand: a solid platform for successful implementation of universal health coverage. Lancet. 2018;391(10126):1205-23.

17. Tangcharoensathien V, Pitayarangsarit S, Patcharanarumol W, Prakongsai P, Sumalee $H$, Tosanguan $J$, et al. Promoting universal financial protection: how the Thai universal coverage scheme was designed to ensure equity. Health Res Policy Syst [Internet]. 2013 2013/08//; 11:[25 p.]. Available from: http://europepmc.org/abstract/MED/23919275.

18. Office of the Council of State. National Health Security Act BE 2545. (2002). In: Office of the Council of State, editor. Thailand: Bangkok: Office of the Council of State; 2002.

19. National Health Security Office. 10 things should know about the rights of universal health coverage Thailand. Bangkok: National Health Security Office; 2013.

20. Office of the Council of State. Constitution of the Kingdom of Thailand B.E. 2540. (1997). In: Council of State, editor. Bangkok: Royal Thai Government Gazette; 1997.

21. Pitayarangsarit $S$. The introduction of the universal coverage of health care in Thailand: policy responses. London: University of London; 2005.

22. Bakir C, Jarvis DSL. Contextualising the context in policy entrepreneurship and institutional change. Policy Society. 2017;36(4):465-78.

23. Kaasch A. Shaping global health policy: global social policy actors and ideas about health care systems. Houndmills, Basingstoke Hampshire; New York, NY: Palgrave Macmillan; 2015. xi, 172 pages $\mathrm{p}$.

24. Yeates N. Understanding Global Social Policy. Policy Press; 2008.

25. Martens K, Niemann D, Kaasch A. International Organisations and the Architecture of Arguments in Global Social Governance. In: Martens K, Niemann D, Kaasch A, editors. International Organizations in Global Social Governance. Global Dynamics of Social Policy. London: Palgrave Macmillan; 2021. pp. 325-39. 
26. Kaasch A. Social policy ideas by the World Bank Comparing Pensions, Health systems and labour policy models. Doctoral Workshop on development and international organisations; 2010. Stockholm.

27. Kaasch A, Stubbs P. Transformations in Global and Regional Social Policies / Edited by Alexandra Kaasch, University of Bremen, Germany, Paul Stubbs, The Institute of Economics, Croatia. Basingstoke; New York: Palgrave Macmillan; 2014. xix, 223 pages $p$.

28. Kaasch A, Sumarto M, Wilmsen B. Transnational Social Policy Development: The Case of Indonesia. New Directions in Social Policy: Alternatives from and for the Global South. Geneva: United Nations Research Institute for Social Development; 2015.

29. Kaasch A, Sumarto M, Wilmsen B. Global Social Policy Actors and Factors in Indonesian Social Policy Making. UNRISD Working Paper. Geneve: United Nations Research Institute for Social Developmen2018.

30. Swyngedouw E. The Mammon Quest: 'Glocalization', Interspatial Competition and the Monetary Order: The Construction of New Scales. In: Dunford M, Kafkalis G, editors. Cities and Regions in the New Europe The Global-Local Interplay and Spatial Development Strategies. London: Belhaven Press; 1992.

31. Kickbusch I. Global + local = glocal public health. J Epidemiol Community Health. 1999;53(8):451-2.

32. de Leeuw E. From Urban Projects to Healthy City Policies. In: de Leeuw E, Simos J, editors. Healthy Cities. New York: Springer; 2017.

33. de Leeuw E. Global and Local (Glocal) Health: The WHO Healthy Cities Programme. Global Change Human Health. 2001;2(1):34-45.

34. de Leeuw E, Tang KC, Beaglehole R. Ottawa to Bangkok-Health promotion's journey from principles to 'glocal' implementation. Health Promot Int. 2006;21(Suppl 1):1-4.

35. Deacon B. Global social policy \& governance. Los Angeles: Sage Publications; 2007. xv, 223 p. p.

36. Kaasch A. Contesting contestation: Global social policy prescriptions on pensions and health systems. Global Social Policy. 2013;13:45-65.

37. Kaasch A. Characterizing Global Health Governance by International Organisations: Is There an Anteand Post-COVID-19 Architecture? In: Martens K, Niemann D, Kaasch A, editors. International Organizations in Global Social Governance. Global Dynamics of Social Policy. London: Palgrave Macmillan; 2021. pp. 233-52.

38. Whiteside A. From MDGs to SDGs: Health slips in global priorities. In: Dalby S, Horton S, Mahon R, Thomaz D, editors. Achieving the Sustainable Development Goals. Routledge Studies in Sustainable Development. London: Routledge; 2019. pp. 36-53.

39. Reich MR, Harris J, Ikegami N, Maeda A, Cashin C, Araujo EC, et al. Moving towards universal health coverage: lessons from 11 country studies. The Lancet. 2016;387(10020):811-6.

40. Prince RJ. Universal Health Coverage in the Global South: New models of healthcare and their implications for citizenship, solidarity and the public good. Michael. 2017;14(2):153-72. 
41. Selway JS. Thailand. A New Constitution and the Introduction of Universal Health Care. In: Selway JS, editor. Coalitions of the Well-being: How Electoral Rules and Ethnic Politics Shape Health Policy in Developing Countries. Cambridge: Cambridge University Press; 2015. pp. 93-137.

42. Kauffman KS, Myers DH. The changing role of village health volunteers in Northeast Thailand: an ethnographic field study. Int J Nurs Stud. 1997;34(4):249-55.

43. Obilade MBBS. Ph.D. TT. Village Health Workers: Considering their Potential Role in the Current Ebola Virus Disease (EVD) Outbreak. International Archives of Medicine. 2015;8.

44. Hesketh T, Wei XZ. Health in China. From Mao to market reform. BMJ. 1997;314(7093):1543-5.

45. Xu S, Hu D. Barefoot Doctors and the "Health Care Revolution" in Rural China: A Study Centered on Shandong Province. Endeavour. 2017;41(3):136-45.

46. Rosenthal MM, Greiner JR. The Barefoot Doctors of China: From Political Creation to Professionalization. Human Organization. 1982;41(4):330-41.

47. Smith AJ. Barefoot doctors and the medical pyramid. Br Med J. 1974;2(5916):429-32.

48. Nitayarumphong S. Evolution of primary health care in Thailand: what policies worked? Health Policy Plan. 1990;5(3):246-54.

49. Lee Y, Kim H. The Turning Point of China's Rural Public Health during the Cultural Revolution Period: Barefoot Doctors: A Narrative. Iran J Public Health. 2018;47(Suppl 1):1-8.

50. Kitschelt HP. Political Opportunity Structures and Political Protest: Anti-Nuclear Movements in Four Democracies. Br J Polit Sci. 1986;16(1):57-85.

51. Kingdon JW. Agendas, Alternatives, and Public Policies. 2nd ed. New York: Pearson; 2003.

52. Capoccia G, Kelemen RD. The Study of Critical Junctures: Theory, Narrative, and Counterfactuals in Historical Institutionalism. World Polit. 2007;59(3):341-69.

53. Brasil FG, Capella ACN. Translating ideas into action: Brazilian studies of the role of the policy entrepreneur in the public policy process. Policy Society. 2017;36(4):504-22.

54. Wibulpolprasert S. 25 Years of the Rural Doctor Movement in Thailand (in Thai). Thailand: Bangkok: World Health Organization; 2003.

55. Rural Doctor Foundation. History of Rural Doctor Foundation (in Thai) n.d. [Available from: http://ruraldoctor.or.th/about/.

56. Nittayarumpong S. On the Way to Achieve Universal Health Coverage Scheme (in Thai). Bangkok: Matichon Publishing; 2007.

57. Puchong R, et al. Rural Doctor Club's Movement and Good Governance in Health System (in Thai). Nonthaburi: Health Systems Research Institute; 2013.

58. Hfocus. Trace back "Universal Health Coverage" reinventing the Thai health system (in Thai) 2014 [Available from: https://www.hfocus.org/content/2014/02/6290.

59. Chokwiwat W. Gold Card Legend: History of Thai Universal Health Coverage System Formation (in Thai). Bangkok: Sri Mueang Printing; 2015. 
60. Limwattananon S, Sakulpanich T. Situation Before Emergence of Universal Health Coverage Scheme in Thailand (in Thai). In: S. S, editor. Thai Health Security System. Bangkok: National Health Security Office; 2012.

61. Pitayarangsarit S, Limwattananon S, Tantivess S, Kharamanond R, Tangcharoensathien V. Local Lvel Responses to Budget Allocation under the Universal Health Care Coverage Policy in Thailand. 2008 14 April 2021. Available from:

http://www.crehs.Ishtm.ac.uk/downloads/publications/Thai_report_final.pdf.

62. Ongsomwang S, Saengtalaeng R. A Brief Lesson Learnt from the Name Lists' Collection for the Draft Law Proposal: A Case Study of National Health Security Act (in Thai) n.d. [Available from: https://www.ilaw.or.th/node/289.

63. Chantarat P. The Role of Rural Doctor Movement on Public Policy Advocacy. A Case Study of Universal Health Coverage Scheme (in Thai). MFU Connexion: Journal of Humanities Social Sciences. 2020;9(1):75-94.

64. Hicken A, Selway JS. Forcing the Genie Back in the Bottle: Sociological Change, Institutional Reform, and Health Policy in Thailand. Journal of East Asian Studies. 2012;12(1):57-88.

65. Kantamaturapoj K, Kulthanmanusorn A, Witthayapipopsakul W, Viriyathorn S, Patcharanarumol W, Kanchanachitra $\mathrm{C}$, et al. Legislating for public accountability in universal health coverage, Thailand. Bull World Health Organ. 2020;98(2):117-25.

66. Mongkhonvanit PT, Hanvoravongchai P. The Impacts of Universalization: A Case Study on Thailand's Social Protection and Universal Health Coverage. In: Yi I, editor. Towards Universal Health Care in Emerging Economies Social Policy in a Development Context. UK: London: Palgrave Macmillan; 2017.

67. Mutiarin D, Darumurti A, Tamronglak A, Whangmahaporn P, editors. Improving Policy Model of Universal Health Coverage Policy: A Comparison Study between Indonesia and Thailand2016.

68. Mutiarin D, Tamronglak A, Suranto S, Darumurti A, Sakir S, editors. Evaluation of Sustainable Universal Health Coverage Finance Policy (UHC): A Comparison Study between Indonesia and Thailand. Moving Towards Evaluation Sustainable Universal Health Coverage Finance Policy: A Comparison Study Between Indonesia and Thailand; 2019: Proceeding ICOGISS 2019.

69. Sumriddetchkajorn K, Shimazaki K, Ono T, Kusaba T, Sato K, Kobayashi N. Universal health coverage and primary care, Thailand. Bull World Health Organ. 2019;97(6):415-22.

70. Stone D. Transfer and translation of policy. Policy Stud. 2012;33(6):483-99.

71. Stone D, Porto de Oliveira O, Pal LA. Transnational policy transfer: the circulation of ideas, power and development models. Policy Society. 2020;39(1):1-18.

\section{Figures}




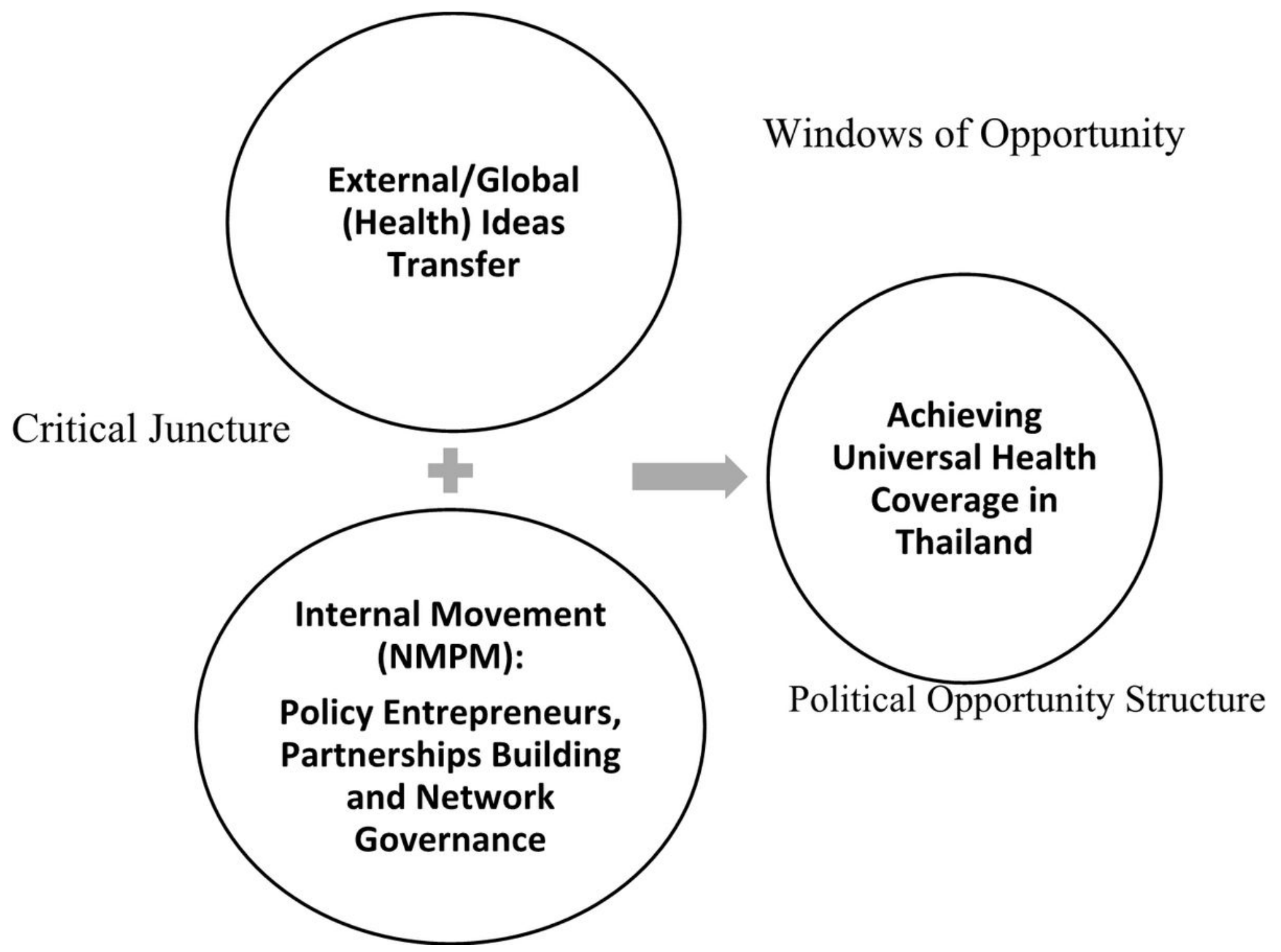

Figure 1

The linkage of external Global (Health) Ideas and Internal Movement for Achieving UHC in Thailand Source: Author's compilation. NMPM = National Medical Professional Movement 